\title{
CAUSITIVE AGENTS OF DECAY OF NORWAY SPRUCE /PICEA ABIES (L.) KARST./ ON THE MOUNTAIN ZVIJEZDA
}

\section{UZROČNICI TRULEŽI DRVETA OBIČNE SMREKE /PICEA ABIES (L.) KARST./ NA PLANINI ZVIJEZDA}

\author{
Kenan ZAHIROVIĆ ${ }^{1}$, Tarik TREŠTIĆ², Azra ČABARAVDIĆ ${ }^{3}$, Mirza DAUTBAŠIĆ3 i Osman MUJEZINOVIĆ ${ }^{3}$
}

\begin{abstract}
SUMMARY
Wood decay fungi reduce the vitality of infected trees, predispose the surrounding trees to be attacked from other harmful agents and damage the most valued part of the stem. Because of these multiple influences it is necessary to explore the presence of these fungi in the forests of Bosnia and Herzegovina, in order to be able to prevent and reduce the damage they cause. Norway spruce in Bosnia and Herzegovina represents one of economically important trees. Because of that, this research is focused on role and implementation of molecular methods and determination of wood decaying fungi on Norway spruce from the genera Heterobasidion and Armillaria on mountain Zvijezda. The reliable identification of species of genus Heterobasidion can be made by analyzing the differences in the structure of the ITS region of rDNA. The reliable identification of species of genus Armillaria can be done by analyzing the differences in the structure of the ITS region of rDNA (genus level), or IGS rDNA regions (interspecies diversity). Inside the object of research were found 9 trees with fungus Heterobasidion parviporum Niemelä \& Korhonen, 1 tree with a fungus Armillaria cepistipes Velenovský, 2 trees with the fungus Armillaria ostoyae (Romagnesi) Herink, and 17 trees whose decay was caused by other decaying fungi. Heterobasidion annosum (Fr.) Bref. was identified from decaying wood of Scots pine (Pinus sylvestris L.).
\end{abstract}

KEY WORDS: Heterobasidion, Armillaria, decaying fungi, DNA analysis, primers, Bosnia and Herzegovina.

\section{INTRODUCTION}

\section{UVOD}

Forests have a special role in life of people because of their polyvalent functions and from economic point of view. Norway spruce in Bosnia and Herzegovina is one of the economically most important tree species. The share of Norway spruce in the total stock of all available forests is about 12\% (Lojo et al., 2011). However, a variety of negative phenomena such as: wood decay, forest fires, various pests, strong winds, and most recently changes of climate conditions, increase the need to improve its health status and quality.

Detection and accurate identification of plant pathogens is one of the most important tasks of monitoring the occurrence of plant diseases and the implementation of preventive and repressive measures. Because of their infectious potential, an early detection of the fungi is very important in aim to prevent their further spread to healthy trees. That

\footnotetext{
1 Dr. sc. Kenan Zahirović, JP Šumsko-privredno društvo Zeničko-dobojskog kantona d.o.o Zavidovićí, Alije Izetbegovića 25, 72220 Zavidovići, Bosna i Hercegovina, e-mail: zahirovic kenan@yahoo.com

${ }_{2}^{2}$ Prof. dr. sc. Tarik Treštić, Šumarski fakultet Univerziteta u Sarajevu, Katedra za zaštitu šuma, urbanog zelenila i lovnog gospodarenja, Zagrebačka 20, 71000 Sarajevo, Bosna i Hercegovina, e-mail: t.trestic@sfsa.unsa.ba

${ }^{3}$ Prof. dr. sc. Azra Čabaravdić, Šumarski fakultet Univerziteta u Sarajevu, Katedra za uređivanje šuma i urbanog zelenila, Zagrebačka 20, 71000 Sarajevo, Bosna i Hercegovina.
} 
is why we need a fast and accurate method for identification of pathogens. Techniques used to identify fungal organisms based on morphological approach are time consuming and require a lot of knowledge of the taxonomy of the pathogen. Other limitations include the difficulty of some species to be grown in vitro (Goud and Termorshuizen, 2003). All limitations and disadvantages of morphological techniques have led to the development of molecular methods for pathogen identification.

The advantage of molecular analysis is that wood decay can be detected in the early stages of development (Tomikawa et al., 1990; Mattheck and Breloer, 1993; Habermehl et al., 1999). Different molecular methods for the detection, identification and quantification of plant pathogenic fungi, are much faster, more accurate and more sensitive. This is one of the reasons why molecular methods are used in our research. Detection of fungal organisms by analysis of DNA isolated directly from the wood were used by other authors too (Nowakowska et al., 2013; Nicolotti et al., 2009; Hantula et al., 1999 and 2003; Guglielmo et al., 2007 and 2009; Škipars et al., 2011).

Decaying fungi reduce the vitality of infested trees and damage the best part of the tree that is used in the production of timber. Because of this multiple influence it is necessary to explore the infectious potential of these fungi in the forests of Bosnia and Herzegovina, in order to be able to prevent and reduce the damage they cause. Spruce in Bosnia and Herzegovina represent one of economically most important trees. Because of that, this research is focused on role and importance of spruce wood rot fungi.

\section{Research Area and Methods - Područje i metode istraživanja}

The research was carried out in the stands of Norway spruce in the area of the mountain Zvijezda, the forest management area "Gornjebosansko", Vareš municipality (Table 1). The object of research was department 65 of economic unit "Gornja Stavnja", where secondary forest of fir and Norway spruce exists on predominantly deep distric cambisole, luvisols, pseudogleys and podsols on silicate and silicate-carbonate sedimentary substrates and acidic volcanic stones. A total area of department 65 is 39.38 ha. Determining the presence of decay was done on harvested trees of Norway spruce in a systematic network of $100 \mathrm{~m}$ x $100 \mathrm{~m}$. Near the intersection points in the network, Norway spruce tree with specific symptoms of decay fungi (decayed wood, fruiting bodies, mycelium, and rhizomorphs) was selected.

The selected trees were harvested and then a sample of wood decay was taken. The samples were collected from three sites of the part of the stem that was affected by the process of decay (base, middle and peak zone of decay). At the sampling points the discs of wood thickness of $5 \mathrm{~cm}$ were cut. Then from each disc the three samples of wood decay were taken (a total of 9 samples per tree). The wood samples were packed in separate bags with data/information on: number of the tree, the part of the stem affected by the decay, as well as the number of the sample.

Probes for DNA isolation were prepared according to the methodology of Tel-Zur et al. (1999). The DNA probe weight was weighed by Sartorius BP 410 with accuracy of 0.01 grams. The DNA probe consisted of a mixture of wood mass of 10-20 mg. From the three samples of wood obtained from the same disk, a unique probe for DNA isolation was prepared. During the preparation of wood mass for isolation of DNA grinding of wood probes by grinder (TissueLyser, Qiagen) served as good solution for avoiding crosscontamination of samples. Besides the wood samples, fruiting bodies of species of the genus Heterobasidion were collected from locality Igman (Table 1). Isolation of DNA from fruiting bodies enables reliable testing of the specificity of the primers used for identification of species of the genus Heterobasidion. Presence of the species Heterobasidion annosum was confirmed on a sample of decayed wood from the Scots pine that was collected in the vicinity of Travnik because it is one of most important decaying fungi on this tree species (Table 1).

Table 1. Locations on which were collected samples of wood decay and fruiting bodies

Tablica 1. Lokacije na kojima je vršeno prikupljanje uzoraka truleži drveta i plodonosnih tijela

\begin{tabular}{ccc}
\hline Datum - Date & Lokalitet - Locality & Koordinate - Coordinates \\
29.03.-01.04.2015. & Vareš & $44^{\circ} 09^{\prime} 51^{\prime \prime} \mathrm{N} ; 18^{\circ} 21^{\prime} 06^{\prime \prime} \mathrm{E}$ \\
15.07.2015. & Igman & $43^{\circ} 44^{\prime} 44^{\prime \prime} \mathrm{N} ; 18^{\circ} 15^{\prime} 41^{\prime \prime} \mathrm{E}$ \\
12.09 .2015$. & Travnik & $44^{\circ} 18^{\prime} 24^{\prime \prime} \mathrm{N} ; 17^{\circ} 42^{\prime} 02^{\prime \prime} \mathrm{E}$
\end{tabular}

The analyses of samples were carried out in the laboratory of the Faculty of Forestry, University of Sarajevo. Amplification of the target segments of DNA was performed in the tubes with prepared reagents (ReadyToGo PCR beads, Amersham Bioscience). The tubes supplemented to $25 \mu \mathrm{l}$ contained: 1.5 units of Taq DNA polymerase, $10 \mathrm{mM}$ Tris- $\mathrm{HCl}$ (pH 9.0 at ambient temperature), $50 \mathrm{mM} \mathrm{KCL}, 1.5 \mathrm{mM}$ $\mathrm{MgCl}_{2}, 200 \mathrm{uM}$ dNTPs and $200 \mathrm{uM}$ stabilizer.

The most frequently used amounts of primers for the ITS region, water and extract DNA in micro tubes for PCR of Heterobasidion spp. were: $1 \mu \mathrm{l}$ of primer MJ-F, $1 \mu \mathrm{l}$ of primer MJ-R, $1 \mu \mathrm{l}$ of primer KJ-F, $1 \mu \mathrm{l}$ of primer KJ-R, $8 \mu \mathrm{l}$ of extract DNA and $13 \mu \mathrm{l}$ of distilled water. This protocol was used by Hantula and Vainio (2003). PCR reactions consisted of an initial denaturation at $95^{\circ} \mathrm{C}$ for 10 minutes, 40 cycles of amplification, and a final extension at $72^{\circ} \mathrm{C}$ for 7 minutes; each cycle of amplification consisted of denaturation at $95^{\circ} \mathrm{C}$ 
for 30 seconds, annealing for 35 seconds at $67^{\circ} \mathrm{C}$, and extension at $72^{\circ} \mathrm{C}$ for 1 minute.

The most frequently used amount of primers, water and extract DNA in micro tubes for PCR for Armillaria spp. (White et al., 1990; Treštić, 2006; Coetzee et al., 2005) were: a) ITS region - $1 \mu$ lof primer ITS- $1,1 \mu$ of primer ITS- 4,8 $\mu \mathrm{l}$ of extract DNA and $15 \mu \mathrm{l}$ of distilled water; b) IGS region - $1 \mu \mathrm{l}$ of primer LR12, $1 \mu \mathrm{l}$ of primer O-1, $8 \mu \mathrm{l}$ of extract DNA and $15 \mu \mathrm{l}$ of distilled water. Amplification of ITS region of the species Armillaria were performed by PCR reactions consisting of an initial denaturation at $95^{\circ} \mathrm{C}$ for 2 minutes and 30 seconds, 30 cycles of amplification (each cycle consisted of denaturation at $95^{\circ} \mathrm{C}$ for 30 seconds, annealing for 30 seconds at $55^{\circ} \mathrm{C}$, and extension at $72^{\circ} \mathrm{C}$ for 30 seconds), and a final extension at $72^{\circ} \mathrm{C}$ for 5 minutes. Amplification of IGS region of the species Armillaria were performed by PCR reactions consisting of an initial denaturation at $95^{\circ} \mathrm{C}$ for 1 minutes and 35 seconds, 30 cycles of amplification (each cycle consisted of denaturation at $95^{\circ} \mathrm{C}$ for 30 seconds, annealing for 40 seconds at $60^{\circ} \mathrm{C}$, and extension at $72^{\circ} \mathrm{C}$ for 2 minutes), and a final extension at $72^{\circ} \mathrm{C}$ for 10 minutes. PCR products were separated by electrophoresis in 2\% (wt/vol) agarose gels in 1X TBE ( $89 \mathrm{mM}$ Tris-borate, $89 \mathrm{mM}$ boric acid, $2 \mathrm{mM}$ EDTA) with ethidium bromide (EtBr) at $100 \mathrm{ng} / \mathrm{ml}$ in the gel and running buffer. DNA bands were visualized by the fluorescence of the intercalated EtBr under UV light and photographed.

PCR products of amplification of IGS region for Armillaria were digested by endonuclease AluI (Amersham Bioscience) in thermocycler. The mixture in tubes for this reaction was prepared by adding the following components: 0.5 $\mu \mathrm{l}$ of the corresponding enzyme-endonuclease, $2.0 \mu \mathrm{l}$ of the supporting buffer to enzyme, $8.0 \mu \mathrm{l}$ of PCR product, $9.5 \mu \mathrm{l}$ of distilled water $\left(\mathrm{dH}_{2} \mathrm{O}\right)$ and then incubated for $6 \mathrm{~h}$ at $37^{\circ} \mathrm{C}$. Restriction fragments were separated by electrophoresis in $2 \%(\mathrm{wt} / \mathrm{vol})$ agarose gels in 1 X TBE $(89 \mathrm{mM}$ Tris-borate, 89 $\mathrm{mM}$ boric acid, $2 \mathrm{mM}$ EDTA) with ethidium bromide (EtBr) at $100 \mathrm{ng} / \mathrm{ml}$ in the gel and running buffer. DNA bands were visualized by the fluorescence of the intercalated EtBr under UV light and photographed.
More reliable interpretation of the profiles on the agarose gel was achieved by adding marker in the two outer lanes. In this study the marker 100 bp DNA Ladder (Carl Roth $\mathrm{GmbH}+\mathrm{Co} . \mathrm{Kg}$ ) was used.

\section{REZULTATI RESULTS}

In order to identify Heterobasidion by PCR amplification of ITS region using total DNA isolated from colonized Norway spruce wood we surveyed 37 samples. The size of segments of ITS region of fungus after amplification are shown in Table 2 and Figure 1. The lanes on the scheme are marked with the first letters of the scientific name (e.g. H. parviporum $H . p$.$) , whereby the first and last lanes labelled "M" represent$ 100 bp DNA Ladder.

PCR amplification of ITS region of Armillaria spp. DNA resulted in 820-860 bp DNA fragments. These DNA fra-

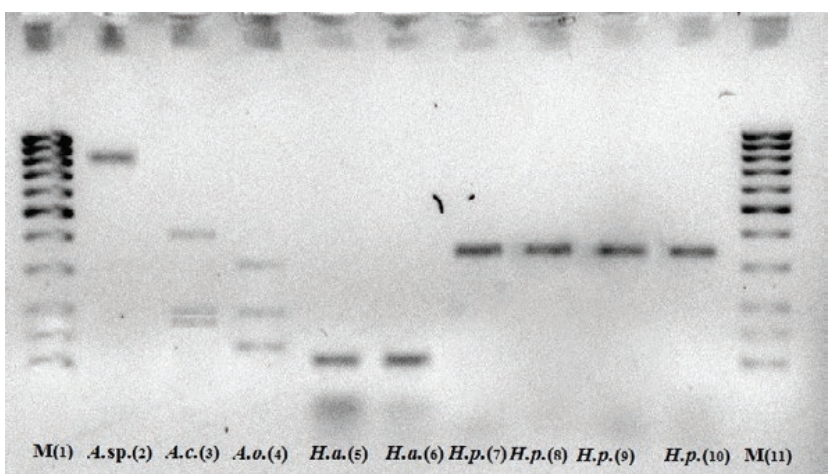

Figure 1. DNA fragments of ITS or IGS profiles of Heterobasidion and Armillaria species

/1:11-markers; 2 - ITS profile of Armillaria group (850 bp); 3 -A. cepistipes profile after digestion of IGS region with $A / u l(399 ; 200 ; 183 \mathrm{bp}) ; 4-A$. ostoyae profile after digestion of IGS region with Alul $(310 ; 200 ; 135 \mathrm{bp}) ; 5$ and 6 - ITS profile of $H$. annosum (100 bp); 7 - ITS profile of $H$. parviporum, DNA isolated from fruiting bodies (350 bp), 8, 9 and 10 - ITS profile of $H$. parviporum, DNA isolated from wood (350 bp)/

Slika 1. DNK segmenti ITS i IGS profila za vrste rodova Heterobasidion i Armillaria

11:11-markeri; 2 - ITS profil roda Armillaria (850 bp); 3 -A. cepistipes profil nakon razgradnje IGS regiona sa $A l u l(399 ; 200 ; 183$ bp); $4-A$. ostoyae profil nakon razgradnje IGS regiona sa $A / u$ I $(310 ; 200 ; 135$ bp); 5 i 6 - ITS profil $H$. annosum (100 bp); 7 - ITS profil H. parviporum, DNK ekstrahiran iz plodišta (350 bp), 8, 9 i 10 - ITS profil H. parviporum, DNK ekstrahiran iz drveta $(350 \mathrm{bp}) /$

Table 2. Size of the PCR amplification products of ITS region of Heterobasidion species

Tablica 2. Veličina PCR segmenata ITS regije za vrste roda Heterobasidion

$\begin{array}{ccccc}\text { Heterobasidion species } & \text { Primer } 1 & \text { Primer 2 } & \text { ITS region (bp) } \\ \text { H. annosum } & \text { MJ-F } & \text { (GGTCCTGTCTGGCTTTGC) } & \text { MJ-R } & \text { (CTGAAGCACACCTTGCCA) } \\ \text { H. parviporum } & \text { KJ-F } & \text { (CCATTAACGGAACCGACGTG) } & \text { KJ-R (GTGCGGCTCATTCTACGCTATC) } & 100 \\ \end{array}$

Table 3. Size of PCR amplification products of IGS region of Armillaria species after digestion with Alul Tablica 3. Veličina PCR segmenata IGS regije za vrste roda Armillaria nakon razgradnje enzimom Alul

$\begin{array}{ccccc}\text { Armillaria species } & & \text { Primer } 1 & \text { Primer 2 } & \text { Digested IGS region (bp) } \\ \text { A. ostoyae } & \text { LR12 } & \text { (GACTTAGAGGCGTTCAG) } & 0-1 \text { (CCGCCAGCGTTCATCCTGAGC) } & 310 ; 200 ; 135 \\ \text { A. cepistipes } & \text { LR12 } & \text { (GACTTAGAGGCGTTCAG) } & 0-1 \text { (CCGCCAGCGTTCATCCTGAGC) } & 399 ; 200 ; 183\end{array}$


Table 4. Causitive agents of wood decay of Norway spruce within the observed stand

Tablica 4. Uzročnici truleži drveta obične smreke u istraživanoj sastojini

\begin{tabular}{lc}
\multicolumn{1}{c}{ Fungal species } & Number of trees \\
Heterobasidion parviporum & 9 \\
Armillaria ostoyae & 2 \\
Armillaria cepistipes & 1 \\
Other decay fungi & 17 \\
No fungal DNA isolation & 8 \\
Total & 37
\end{tabular}

gments did not allow adequate differentiation of Armillaria species. For identification of species of Armillaria group digestion of IGS region with AluI was used (Table 3). According to this results $A$. ostoyae and A. cepistipes were identified as wood rot fungi of Norway spruce.

Among 37 analysed samples, 28 resulted in successful fungal DNA isolation. Twelve DNA isolates were identified as species of Heterobasidion or Armillaria. Other causitive agents of wood decay, according to size of DNA fragments of ITS region, belonged to group of other fungi. Identification of species of this group is not done yet (Table 4).

\section{DISCUSSION}

\section{RASPRAVA}

DNA of wood decay fungi was isolated directly from infected wood. In most cases, enough quantity of DNA was obtained from decayed wood mass of 10-20 mg, but in several samples DNA wasn't isolated because of small quantity of fungal tissue in the wood. Identification of Heterobasidion species was carried out using species specific primers. Specifity of primers MJ-F and MJ-R for identification of $H$. annosum (100 bp fragment) and primers KJ-F and KJ-R for identification of $H$. parviporum (350 bp fragment) was confirmed for use in Bosnia and Herzegovina. Previously, specificity of these primers was confirmed by Hantula and Vainio (2003) for use in the Scandinavian region.

Nine of 37 DNA samples isolated from decayed wood of Norway spruce (Table 3) were identified as H. parviporum, which was expected, since this species most commonly occurs on Norway spruce (Łakomy and Werner, 2003; Niemelä and Korhonen, 1998; Korhonen et al., 1997). According to Lockman et al. (2016) fungi of the genus Heterobasidion in mixed stands of conifers are causative agents of wood decay on about $9 \%$ of the trees, while in the stands of Norway spruce they cause rot on about $14 \%$ of the trees. Lehtijarvi et al. (2012) found in Abies nordmanniana ssp. bornmülleriana that $33 \%$ of the decay on the trees was caused by fungi of the genus Heterobasidion. H. annosum was not detected within the object of research, as it occurs most frequently on Scots pine (Łakomy and Werner, 2003; Niemelä and Korhonen, 1998; Korhonen et al., 1997). Specificity of the primers for this species was tested on DNA isolated from the decayed wood of Scots pine, collected from the site near Travnik (Table 2, Figure 1).

In case of Armillaria species, there are numerous methods of identifying these species using the techniques of PCR and AFLP or RFLP. ITS region is less used in studies of the genus Armillaria because it is more uniform and requires the application of a large number of enzymes for its digestion. More recently, for the identification of species of this genus IGS-1 region of DNA is used. PCR amplification of this region is achieved with primers LR12R and O-1 (Duchesne and Anderson, 1990). The best results in the digestion of IGS region are obtained with AluI. Treštić (2006) performed the reliable identification of fungi of the genus Armillaria by analysis of differences in the structure of the ITS and IGS regions of rDNA which was previously obtained from rhizomorphs. In the identification process, the following endonuclease were used: AluI, TaqI and Hinfl. Three species were identified: A. cepistipes, A. gallica and A. ostoyae. In the research of Keča et al. (2006), in Serbia, A. cepistipes, A. ostoyae, A. mellea, A. gallica and $A$. tabescens were identified by analysing IGS region of their DNA.

For the purposes of this research, Armillaria fungi were determined, in the first step, according to the size of the ITS region obtained by using primers ITS1 and ITS4. DNA fragments were $820-860 \mathrm{bp}$. Reliable identification of $A$. ostoyae and A. cepistipes was carried out by digestion of the IGS region with endonuclease AluI (a second step).

Both species appear on conifers, but A. cepistipes is more characteristic for Norway spruce. The results obtained in this research are not sufficient for detailed studies of the structure of the populations of the present species of fungi of the genera Heterobasidion and Armillaria, but they provide basic data for future research in terms of optimizing the process of identifying fungi species of these two genera. PCR amplification of the ITS region of numerus isolates of DNA resulted in products of 630-650 bp. Determination of the species of fungi from this group would require significant material costs and therefore was not carried out. Out of 37 analysed samples 17 belong to this group (Table 4). According to Jasalavich et al. (2000), which conducted research using primers ITS-1F and ITS- $4 \mathrm{~B}$, it was found that these primers can detect many fungi that cause white and brown rot. The extraction of the DNA was unsuccessful on 8 samples. It was not clear which group of microorganisms cause decay of wood on these samples. It is possible that they are decayed by bacteria or that the fungal DNA is significantly damaged and decomposed by their activity, which prevented its extraction.

\section{CONCLUSIONS}

\section{ZAKLJUČCI}

According to the results of this research, the reliable identification of species of genus Heterobasidion can be made by 
analysing the differences in the structure of the ITS region of rDNA isolated directly from the wood of Norway spruce and Scots pine or fruiting bodies of fungi. The specificity of the primers $\mathrm{KJ}-\mathrm{F}$ and $\mathrm{KJ}-\mathrm{R}$ for the fungus $\mathrm{H}$. parviporum and primers MJ-F and MJ-R for the fungus H. annosum in Bosnia and Herzegovina is confirmed. H. parviporum was identified on 9 from 37 analysed wood samples.

The reliable identification of species of genus Armillaria can be performed by analysing the differences in the structure of the ITS region of rDNA (genus level), or IGS rDNA regions (interspecies diversity) isolated from Norway spruce wood. By digestion of IGS region with endonuclease AluI A. ostoyae and A. cepistipes on Norway spruce were identified. These fungi were on 3 from 37 analysed wood samples.

Molecular analyses did not reveal any cases in which on the investigated decayed wood of Norway spruce simultaneously occur $H$. parviporum and Armillaria species or in a combination with other decay fungi. This indicates a significant infectious potential of these fungi and probably also their mutual antagonistic relationship.

In the coming period, continue research of population structure Heterobasidion and Armillaria species in Bosnia and Herzegovina is needed and additional efforts in the identification of other fungi species that cause wood decay. That would be one of the positive developments in forestry science and profession in the coming period because without a detailed knowledge about species of harmful agents it is impossible to plan or implement effective measures with aim of their control and suppression.

\section{REFERENCES}

\section{LITERATURA}

- Coetzee, M.P.A., B.D. Wingfield, P. Bloomer, M.J. Wingfield, 2005: Phylogenetic analyses of DNA sequences reveal species partitions amongst isolates of Armillaria from Africa. Mycologia 109. pp. 1-12.

- Duchesne, L.C., J.B. Anderson, 1990: Location and direction of transcription of the 5S rRNA gene in Armillaria. Mycological research 94(2). pp. 266-268.

- Goud, J.C., A.J. Termorshuizen, 2003: Quality of methods to quantify microsclerotia of Verticillium dahliae in soil. European Journal of Plant Pathology. Vol.109. No.6. pp. 523-534. ISSN 0929-1873.

- Guglielmo, F., S.E. Bergmann, P. Gonthier, G. Nicolotti, M. Garbelotto, 2007: A multiplex PCR-based method for the detection and early identification of wood rotting fungi in standing trees. J Appl Microbiol. 103(5). pp.1490-1507.

- Guglielmo, F., P. Gonthier, G. Nicolotti, M. Garbelotto, 2009: Optimization of sampling procedures for DNA-based diagnosis of wood decay fungi in standing trees. Journal compilation. The Society for Applied Microbiology.

- Habermehl, A., H.W. Ridder, P. Seidl, 1999: Computerized tomographic systems as tools for diagnosing urban tree health. Acta Horticoltura 496. pp. 261-268.
- Hantula, J., E. Vainio, 1999: Variation of RAMS markers within the intersterility groups of Heterobasidion annosum in Europe. European Journal of Forest Pathology Volume 29. Issue 3. pp. 231-246.

- Hantula, J., E. Vainio, 2003: Specific primers for differentiation of Heterobasidion annosum and $H$. parviporum infected stumps in Northern Europe. Silva Fennica 37(2). pp. 181-187.

- Jasalavich, C.A., A. Ostrofsky, J. Jellison, 2000: Detection and Identification of Decay Fungi in Norway spruce Wood by Restriction Fragment Length Polymorphism Analysis of Amplified Genes Encoding rRNA. Applied and Environmental Micobiology. pp. 4725-4734.

- Keča, N., W.J.A. Bodles, S. Woodward, D. Karadžić, S. Bojović, 2006: Molecular-based identification and phylogeny of Armillaria species from Serbia and Montenegro. For. Pathol. 36. pp. 41-57.

- Korhonen, K., N.I. Fedorov, N.L. Porta, N.P. Kovbasa, 1997: Abies sibirica in the Ural region is attacked by the S type of Heterobasidion annosum. In Heterobasidion annosum: biology, ecology, impact and control. Wallingford. UK. Edited by S. Woodward, J. Stenlid, R. Karjalainen and A. Hüttermann. CAB International. Wallingford. UK. pp. 35-70; 94-104.

- Łakomy P., A. Werner, 2003: Distribution of Heterobasidion annosum intersterlility groups in Poland. For. Path. 33. pp. 1-8.

- Lehtijarvi, A., H.T.D. Lehtijarvi, S. Ünal, M. Karadeniz, A.G.A. Kaya, F. Oskay, 2012: Heterobasidion Infection in Abies nordmanniana ssp. bornmülleriana Stands in Kastamonu Province. Kastamonu Üni. Orman Fakültesi Dergisi, Özel Sayı: pp. 271274.

- Lockman, I. B., S.J. Holly, 2016: Forest root diseases across the United States. Gen. Tech. Rep. RMRS-GTR-342. Ogden, UT: U.S. Department of Agriculture. Forest Service, Rocky Mountain Research Station. 55 p.

- Lojo, A., B. Balić, T. Treštić, S. Vojniković, Ć. Višnjić, A. Čabaravdić, S. Delić, J. Musić, 2011: Druga inventura šuma na velikim površinama u Bosni i Hercegovini (preliminarni podaci).

- Mattheck, C., H. Breloer, 1993: Feldaleitung fur Baumkkontrollen mit VTA Gartenamt 42. pp. 110-116.

- Nicolotti, G., P. Gonthier, F. Guglielmo, M. Garbelotto, 2009: A biomolecular method for the detection of wood decay fungi: a focus on tree stability assessment. Arboriculture and Urban Forestry. ISA. pp. 14-18.

- Škipars, V., D. Rungis, 2011: Detection of Heterobasidion annosum on Scots pine trees using a polymerase chain reaction based method. Issued by the Institute of Forestry. Lithuanian Research Centre for Agriculture and Forestry. pp. 1-11.

- Tel-Zur, N., S. Abbo, D. Myslabodski, Y. Mizrahi, 1999: Modified CTAB procedure for DNA isolation from epiphytic cacti of genera Hylocereus and Selenicereus (Cactaceae). Plant Molecular Biology Reporter 17. pp. 249-254.

- Treštić, T., 2006: Gljive roda Armillaria prašumskih i gospodarskih šuma bukve i jele sa smrčom u centralnoj Bosni. Univerzitet u Sarajevu. Šumarski fakultet. pp. 48-57.

- Tomikawa, Y., Y. Iwase, K. Arita, H. Yamada, 1990: Non destructive inspection of wooden poles using ultrasonic computed tomography. IEEE Transac UFFC 33. pp. 354-358.

- White, T.J., T. Bruns, S. Lee, J.W. Taylor, 1990: Amplification and direct sequencing of fungal ribosomal RNA genes for phylogenetics. In: Innis MS. Gelfand DH (eds) PCR protocols: a guide to methods and applications. City Publisher. pp. 322-615. 


\section{SAŽETAK}

Utjecaj gljiva truležnica roda Heterobasidion i Armillaria na pojavu truleži na stablima obične smreke provedeno je na Šumskogospodarskom području "Gornjebosansko", gospodarska jedinica "Gornja Stavnja”, odjeljenje 65. Utvrđivanje prisutnosti truleži vršeno je na srušenim stablima obične smreke na premjernim površinama koje su raspoređene u sistematski postavljenoj mreži $100 \mathrm{~m}$ x $100 \mathrm{~m}$. Uzorci su prikupljeni sa tri mjesta na dijelu debla zahvaćenom procesom truleži (početak zone truleži, sredina i vršna zona truleži). Na mjestima uzorkovanja uzimani su kolutovi drva debljine $5 \mathrm{~cm}$. Analize uzoraka su provedene u laboratorijima Šumarskog fakulteta Univerziteta u Sarajevu. Za izravnu izolaciju gljivične DNA su pripremljeni uzroci drva mase 10-20 mg. Za amplifikaciju ciljanog segmenta DNK korištene su tubice s pripremljenim reagensima, proizvod ReadyToGo PCR beads tvrtke Amersham, Bioscience. Za amplifikaciju ciljanog segmenta ITS regije za rod Heterobasidion su korišteni početnice MJ-F, MJ-R, KJ-F i KJ-R, pomoću kojih je utvrđena međuvrsna raznolikost (tablica 2). Za amplifikaciju ciljanog segmenta ITS regiona za rod Armillaria su korišteni početnice ITS-1 i ITS-4, pomoću kojih je utvrđena samo pripadnost rodu. Za međuvrsnu raznolikost je vršena amplifikacija ciljanog segmenta IGS regiona za rod Armillaria pomoću početnice LR12 i O-1, te razgradnja endonukleazom AluI (tablica 3). Uspješnost amplifikacije je provjerena elektroforezom na agaroznom gelu. Interpretacija profila je izvršena pomoću molekularnog markera poznate veličine (100 bp) (slika 1).

$\mathrm{Na}$ osnovi provedenih istraživanja unutar istraživane sastojine utvrđeno je 9 stabala s gljivom $H$. parviporum, 2 stabla s gljivom A. ostoyae, 1 stablo s gljivom $A$. cepistipes, te 17 stabala čiju trulež su uzrokovale ostale gljive truležnice (tablica 4). Gljiva $H$. annosum je uspješno identificirana iz plodišta. $\mathrm{Na}$ osnovi svega navedenog, može se zaključiti da je molekularnim analizama moguće utvrđivati međuvrsnu raznolikost gljiva ova dva roda iz uzoraka drveta sa truleži i plodišta gljiva.

KLJUČNE RIJEČI: Heterobasidion, Armillaria, gljive truležnice, molekularne analize, početnice, Bosna i Hercegovina. 